\title{
THE BIG FIVE PERSONALITY DIMENSIONS AND JOB PERFORMANCE
}

\author{
S ROTHMANN \\ E P COETZER \\ Research Programme "Human Resource Management for Development" Research Unit "Decision- \\ making and Management for Economic Development" PU for CHE
}

\begin{abstract}
The objective of this research was to determine the relationship between personality dimensions and job performance. A cross-sectional survey design was used. The study population consisted of 159 employees of a pharmaceutical company. The NEO-Personality Inventory - Revised and Performance Appraisal Questionnaire were used as measuring instruments. The results showed that Emotional Stability, Extraversion, Openness to Experience and Conscientiousness were related to task performance and creativity. Three personality dimensions, namely Emotional Stability, Openness to Experience and Agreeableness, explained 28\% of the variance in participants' management performance.
\end{abstract}

\section{OPSOMMING}

Die doelstelling van hierdie navorsing was om die verband tussen persoonlikheidsdimensies en werksprestasie te bepaal. ' $n$ Eenmalige dwarsdeursnee-ontwerp is gebruik. Die ondersoekgroep het bestaan uit 159 werknemers binne ' $n$ farmaseutiese organisasie. Die NEO-Personality Inventory - Revised en die Prestasiebeoordelingsvraelys is as meetinstrumente gebruik. Die resultate het aangetoon dat Emosionele Stabiliteit, Ekstroversie en Konsensieusheid met taakverrigting en kreatiwiteit verband hou. Drie persoonlikheidsdimensies, naamlik Emosionele Stabiliteit, Openheid vir Ervaring en Inskiklikheid, het $28 \%$ van die variansie in bestuursprestasie (soos beoordeel deur toesighouers) voorspel.

The relationship between personality and job performance has been a frequently studied topic in industrial psychology in the past century (Barrick, Mount \& Judge, 2001). Job performance is a multi-dimensional construct which indicates how well employees perform their tasks, the initiative they take and the resourcefulness they show in solving problems. Furthermore, it indicates the extent to which they complete tasks, the way they utilise their available resources and the time and energy they spend on their tasks (Boshoff \& Arnolds, 1995; Schepers, 1994).

Job performance could be affected by situational factors, such as the characteristics of the job, the organisation and co-workers (Hackman \& Oldham, 1980; Strümpfer, Danana, Gouws \& Viviers, 1998), and by dispositional factors. Dispositional variables can be described as personality characteristics, needs, attitudes, preferences and motives that result in a tendency to react to situations in a predetermined (predisposed) manner (House, Shane \& Herrold, 1996). Job performance is influenced by aptitude, need for achievement, self-regard, locus of control, affective temperament and the interaction between these constructs (Boshoff \& Arnolds, 1995, Wright, Kacmar, McMahan $\&$ DeLeeuw, 1995)

Traditionally industrial psychologists have questioned the usefulness of personality measures in predicting job-related criteria (such as job performance), because of pessimistic conclusions of early reviews of the topic (e.g. Guion \& Gottier, 1965) and concerns that most personality measures are faked (Reilly \& Warech, 1993). However, evidence has suggested that personality measures are valid predictors of diverse job-related criteria (Goldberg, 1993). Unlike many measures of cognitive ability, personality measures typically do not have an adverse impact on disadvantaged employees (Hogan, Hogan \& Roberts, 1996) and thus can enhance fairness in personnel decisions. Recent research showed that personality dimensions are related to job performance (Rosse, Stecher, Miller \& Levin, 1998; Wright et al., 1995).

In this research the relationship between personality dispositions and job performance is studied from a trait

Requests for copies should be addressed to: $S$ Rothmann, Programme in Industrial Psychology, PU for CHE, Private Bag X6001, Potchefstroom, 2520 perspective, and more specifically the five-factor model of personality dimensions as conceptualised by Costa and McCrae (1992). The five-factor model of personality represents a structure of traits, developed and elaborated over the last five decades. Factors are defined by groups of intercorrelated traits, which are referred to as facets (McCrae \& Costa, 1997). The fivefactor model of personality as measured by the Neo-Personality Inventory Revised (NEO-PI-R) includes Neuroticism, Extraversion, Openness, Agreeableness and Conscientiousness (McCrae \& Costa, 1997). The reason for deciding on this conceptualisation is because the validity of broad personality dimensions is superior too narrowly defined dimensions (Ashton, 1998).

The results of various studies and meta-analyses (Barrick \& Mount, 1991; Hough, Eaton, Dunnette, Kamp \& McCloy, 1990; Salgado, 1997; Tett, Jackson \& Rothstein, 1991; Vinchur, Schippmann, Sweizer \& Roth, 1998) showed that various big five personality dimensions are related to job performance. Barrick and Mount (1991) and Salgado (1997) found that conscientiousness is one of the best predictors of job performance in the United States of America and Europe. De Fruyt and Mervielde (1999), Tokar and Subich (1997), Schneider (1999) and Vinchur et al. (1998) concluded that Extraversion and Conscientiousness predict job performance in various occupations. However, these studies have all been carried out elsewhere in the world and in other contexts. In South Africa, the use of psychometric tests in studies of job performance is still a controversial issue. Research regarding the relationship between personality dimensions and job performance is therefore necessary. If relationships between personality dimensions and job performance are found, the results could be used for recruitment, selection and career development purposes.

The objective of this research was to determine the relationship between personality dimensions and job performance of employees in a pharmaceutical group.

The role of personality dimensions in job performance Researchers agree that almost all personality measures could be categorised according to the five-factor model of personality 
(also referred to as the "big five" personality dimensions) (Goldberg, 1990; Hogan et al., 1996). The five personality dimensions seem to be relevant to different cultures (McCrae \& Costa, 1997) and have been recovered consistently in factor analyses of peer- and self-ratings of trait descriptors involving diverse conditions, samples, and factor extraction and rotation methods (Costa \& McCrae, 1988). Research also showed that the five personality factors have a genetic basis (Digman, 1989) and that they are probably inherited (Jang, Livesley \& Vernon, 1996). The five dimensions of the five-factor model of personality are Neuroticism, Extraversion, Openness to Experience, Agreeableness and Conscientiousness.

- Neuroticism. Neuroticism is a dimension of normal personality indicating the general tendency to experience negative affects such as fear, sadness, embarrassment, anger, guilt and disgust. High scorers may be at risk of some kinds of psychiatric problems. A high Neuroticism score indicates that a person is prone to having irrational ideas, being less able to control impulses, and coping poorly with stress. A low Neuroticism score is indicative of emotional stability. These people are usually calm, even-tempered, relaxed and able to face stressful situations without becoming upset (Hough et al., 1990). Hörmann and Maschke (1996) found that Neuroticism is a predictor of performance in various occupations. Dunn, Mount, Barrick and Ones (1995) showed that emotional stability (the opposite of Neuroticism) is the second most important characteristic that affects the employability of candidates. In a recent study Judge, Higgins, Thoresen and Barrick (1999) found that Neuroticism is inversely related to job performance. However, according to Salgado (1997), Neuroticism predicts job performance in certain circumstances.

- Extraversion. Extraversion includes traits such as sociability, assertiveness, activity and talkativeness. Extraverts are energetic and optimistic. Introverts are reserved rather than unfriendly, independent rather than followers, even-paced rather than sluggish. Extraversion is characterised by positive feelings and experiences and is therefore seen as a positive affect (Clark \& Watson, 1991). It was found that Extraversion is a valid predictor of performance in jobs characterised by social interaction, such as sales personnel and managers (Barrick \& Mount, 1991; Bing \& Lounsbury, 2000; Lowery \& Krilowicz, 1994; Vinchur et al., 1998). Johnson (1997) found a positive relationship between Extraversion and job performance of police personnel, and explained this relationship in terms of the high level of interaction in the police service.

- Openness to Experience. Openness to Experience includes active imagination, aesthetic sensitivity, attentiveness to inner feelings, a preference for variety, intellectual curiosity and independence of judgement. People scoring low on Openness tend to be conventional in behaviour and conservative in outlook. They prefer the familiar to the novel, and their emotional responses are somewhat muted. People scoring high on Openness tend to be unconventional, willing to question authority and prepared to entertain new ethical, social and political ideas. Open individuals are curious about both inner and outer worlds, and their lives are experientially richer. They are willing to entertain novel ideas and unconventional values, and they experience both positive and negative emotions more keenly than do closed individuals. Research has shown that Openness to Experience is related to success in consulting (Hamilton, 1988), training (Barrick \& Mount, 1991; Vinchur et al., 1998) and adapting to change (Horton, 1992; Raudsepp, 1990). In contrast, Johnson (1997) and Hayes, Roehm and Castellano (1994) found that successful employees (compared with unsuccessful employees) obtained significantly lower scores on Openness. Tett et al. (1991) reported that Openness to Experience is not a valid predictor of job performance. A possible explanation for the contradictory results regarding the relationship between Openness to Experience and job performance is that different jobs have different requirements.

- Agreeableness. An agreeable person is fundamentally altruistic, sympathetic to others and eager to help them, and in return believes that others will be equally helpful. The disagreeable/antagonistic person is egocentric, sceptical of others' intentions, and competitive rather than co-operative. According to Tett et al. (1991), Agreeableness is a significant predictor of job performance. Salgado (1997) found that Agreeableness is related to training success. The co-operative nature of agreeable individuals may lead to success in occupations where teamwork and customer service are relevant (Judge et al., 1999).

- Conscientiousness. Conscientiousness refers to self-control and the active process of planning, organising and carrying out tasks (Barrick \& Mount, 1993). The conscientious person is purposeful, strong-willed and determined. Conscientiousness is manifested in achievement orientation (hardworking and persistent), dependability (responsible and careful) and orderliness (planful and organised). On the negative side, high Conscientiousness may lead to annoying fastidiousness, compulsive neatness or workaholic behaviour. Low scorers may not necessarily lack moral principles, but they are less exacting in applying them. Borman, White, Pulakos and Oppler (1991) and Hough et al. (1990) found a correlation of 0,80 between reliability (an aspect of Conscientiousness) and job performance. Various researchers (Barrick \& Mount, 1991; Barrick, Mount \& Strauss, 1993; Frink \& Ferris, 1999; Ones \& Viswesvaran, 1997; Sackett \& Wannek, 1996) reported significant correlations between Conscientiousness and job performance. According to Sackett and Wannek (1996), the relationship between Conscientiousness and job performance could be attributed to the conceptual relationship between Conscientiousness and integrity. Furthermore, autonomy and goal setting influence the relationship between Conscientiousness and job performance (Barrick \& Mount, 1993; Barrick et al., 1993).

To the lay person it is a self-evident fact that personality factors play an important part in job performance. Yet the psychological literature in this regard is equivocal. Schmitt, Gooding, Noe and Kirsch (1984) found in a meta-analysis of validation studies of personality measures an average validity coefficient of $r=0,21$. However, Barrick and Mount (1991) concluded that there are grounds for optimism concerning the use of standard personality tests to predict performance of employees.

Hayes et al. (1994) found that supervisor ratings of specific performance criteria and overall job effectiveness were related positively to Conscientiousness and inversely to Openness and Extraversion in a sample of automobile machine operators. In a sample of sewing machine operators, Krilowicz and Lowerey (1996) found significant positive relations between operator productivity and traits corresponding closely with Conscientiousness and Extraversion. Hörmann and Maschke (1996) found that personality variables, especially those reflecting Neuroticism, predicted variance in pilot performance beyond that explained by flying experience, age and grade in a simulator check flight. Substandard pilots were more neurotic than successful pilots. In a sample of nursing service employees, Day and Bedeian (1995) found that the more similar in Agreeableness employees were to their co-workers, the more positive supervisors' ratings of performance were.

Salgado (1997) conducted a meta-analysis of the five-factor personality dimensions in relation to performance for three criteria (i.e., supervisory ratings, training ratings and personnel data) and for five occupational groups using 36 validity studies conducted in Europe. Results indicated that Conscientiousness and Emotional Stability were valid 
predictors for all performance criteria and for most occupational groups. Extraversion predicted manager and police performance, and Openness to Experience predicted police and skilled labour performance.

Because items on many personality inventories are transparent, and thus easily faked, researchers are often concerned about the potential effect of response distortion on the prediction of performance from personality measures. However, Ones, Viswesvaran and Reiss (1996) found that social desirability had no effect on the predictive validity of the big five personality dimensions. Furthermore, Barrick and Mount (1996) reported that Conscientiousness and Emotional Stability (i.e. low Neuroticism) positively predicted supervisor performance ratings for truck drivers and that, when adjusted for social desirability, the validity coefficients were not attenuated significantly.

Several studies reported research evidence suggesting that personality is related differently to different dimensions of job performance. Using a sample of hotel workers, Stewart and Carson (1995) related Conscientiousness, Extraversion and Agreeableness to three different performance variables (i.e. citizenship, dependability and work output) and found significant validity coefficients for Conscientiousness and Extraversion, but for different sets of criteria. Conscientiousness positively predicted dependability and work output, and Extraversion inversely predicted citizenship and dependability.

\section{METHOD}

\section{Research design}

A survey design was used to achieve the research objectives. The specific design was the cross-sectional design, by means of which a sample is drawn from a population at a particular point in time (Shaughnessy \& Zechmeister, 1997).

\section{Sample}

The sample includes employees of a corporate pharmacy group with 14 retail and 16 hospital pharmacies in the North West Province, Free State, Mpumalanga and Gauteng, as well as a head office $(N=159)$. The total population of pharmacists ( $n=$ $59)$ and non-pharmacists $(n=100)$ was included in the empirical study. All pharmacists had a B.Pharm. degree or a Diploma in Pharmacy, while the qualifications of nonpharmacists varied from Grade 10 to a master's degree. About $57 \%$ of the sample had some form of post-school education. The total population of employees participated in the research. Approximately $83 \%$ of the sample consisted of females. The ages of the participants varied between 18 and 58 years, with $53 \%$ in the age group between 21 and 30 . A total of $57,2 \%$ of the participants were married.

\section{Measuring instruments}

The NEO Personality Inventory Revised (NEO-PI-R) (Costa \& McCrae, 1992) was used to measure the personality of individuals, based on the five-factor model of personality, which includes the dimensions of Extraversion, Neuroticism, Agreeableness, Openness to experience and Conscientiousness. The five personality dimensions are each divided into six facets. The NEO-PI-R has 240 items (Costa \& McCrae, 1992). The Cronbach alpha coefficients of the personality dimensions vary from 0,86 (Openness) to 0,92 (Neuroticism), and those of the personality facets from 0,56 (Tender-minded) to 0,81 (Depression). Costa and McCrae (1992) report test-retest reliability coefficients (over six years) for Extraversion, Neuroticism and Openness varying from 0,68 to 0,83 and for Agreeableness and Conscientiousness (over three years) of 0,63 and 0,79 respectively. Costa and McCrae (1992) showed construct validity for the NEO-PI-R for different gender, race and age groups.
The Performance Appraisal Questionnaire (PAQ) (Schepers, 1994) was used to measure pharmacists' job performance. The PAQ consists of 30 items which measure three scales, namely Performance, Creativity and Management skills. Acceptable Cronbach alpha coefficients were found for the questionnaire. Supervisor ratings (on a 9-point scale) of the performance of employees were used. All supervisors had undergone a halfday intensive rater-training course to ensure that they were aware of and able to avoid common pitfalls. The scales of the PAQ have acceptable alpha coefficients (Schepers, 1994). Construct validity of the PAQ is demonstrated by the fact that factor loadings between 0,41 and 0,98 were obtained (Schepers, 1994).

\section{Statistical analysis}

The statistical analysis was carried out by means of the SAS program (SAS Institute, 1996). Descriptive statistics (means, standard deviations, skewness and kurtosis) were used to analyse the results. Cronbach alpha coefficients and inter-item correlations were used to assess the internal consistency of the measuring instruments (Clark \& Watson, 1995). Coefficient alpha conveys important information regarding the proportion of error variance contained in a scale. According to Clark and Watson (1995), the average inter-item correlation coefficient (which is a straightforward measure of internal consistency) is a useful index to supplement information supplied by coefficient alpha. However, unidimensionality of a scale cannot be ensured simply by focusing on the mean inter-item correlation - it is necessary to examine the range and distribution of these correlations as well.

Pearson product-moment correlation coefficients were used to specify the relationships between the variables. Because a nonprobability sample was used in this research, effect sizes (rather than inferential statistics) were used to decide on the significance of the findings. A cut-off point of 0,30 (medium effect, Cohen, 1988) was set for the practical significance of correlation coefficients. Canonical correlation was used to determine the relationships between the dimensions of burnout, personality traits and coping strategies. The goal of canonical correlation is to analyse the relationship between two sets of variables (Tabachnick \& Fidell, 2001). Canonical correlation is considered a descriptive technique rather than a hypothesistesting procedure.

A stepwise multiple regression analysis was conducted to determine the proportion of variance in Management Performance that is predicted by personality dimensions. The effect size (which indicates practical significance) in the case of multiple regression is represented by the following formula (Steyn, 1999):

$f^{2}=\mathrm{R}^{2} /\left(1-R^{2}\right)$

A cut-off point of 0,35 (large effect, Steyn, 1999) was set for the practical significance of $f^{2}$.

\section{RESULTS}

The descriptive statistics of the PAQ for the sample are given in Table 1.

TABLe 1

DESCRIPTIVE STATISTICS OF THE PAQ

\begin{tabular}{lcccccc}
\hline Item & Mean & SD & Skewness & Kurtosis & $\boldsymbol{r}$ (Mean) & $\alpha$ \\
\hline Task Performance & 59,05 & 9,87 & $-1,03$ & 1,70 & 0,48 & 0,88 \\
Creativity & 57,30 & 13,58 & $-0,48$ & 0,15 & 0,71 & 0,96 \\
Management & 58,84 & 13,67 & $-0,50$ & $-0,45$ & 0,70 & 0,96 \\
\hline
\end{tabular}


Table 1 shows that above average scores were obtained on the three dimensions of the PAQ. Regarding skewness and kurtosis, it is clear that the results were somewhat skew regarding Task Performance. This skewness may be attributed to the fact that poor performers on this dimension probably left the organisation. Scores on the other dimensions seem to be normally distributed. Table 1 shows that high Cronbach alpha coefficients were obtained for all the factors (Nunnally $\&$ Bernstein, 1994). The correlation coefficients between the items of scales $(0,48 \leq r \leq 0,70)$ indicate that the items correlate too highly (Clark \& Watson, 1995). However, this should be seen in the context of the specificity of the constructs that are measured.

Table 2 shows the descriptive statistics, Cronbach alpha coefficients and inter-item correlation coefficients of the NEO-PI-R.

TABLE 2

DESCRIPTIVE STATISTICS OF THE NEO PI-R

\begin{tabular}{lcccccc}
\hline Item & Mean & $\boldsymbol{S D}$ & Skewness & Kurtosis & $\boldsymbol{r}$ (Mean) & $\alpha$ \\
\hline Neuroticism & 88,73 & 24,34 & 0,08 & 0,10 & 0,49 & 0,86 \\
Extraversion & 115,53 & 22,53 & 0,23 & 0,28 & 0,46 & 0,83 \\
Openness & 111,82 & 16,65 & 0,43 & $-0,06$ & 0,36 & 0,77 \\
Agreeableness & 127,20 & 18,45 & 0,07 & 0,26 & 0,36 & 0,76 \\
Conscientiousness & 132,68 & 17,48 & $-0,31$ & 0,13 & 0,38 & 0,78 \\
\hline
\end{tabular}

Table 2 shows that the participants (compared with American norms) measured average on the five personality dimensions. Regarding skewness and kurtosis, the values in Table 2 show minor deviations from 0 , an indication that the scores are relatively normally distributed. The Cronbach alpha coefficients for the five personality dimensions vary from 0,76 (Agreeableness) to 0,86 (Neuroticism). These alpha coefficients could be regarded as acceptable when they are compared with the cut-off point of 0,80 recommended by Nunnally and Bernstein (1994). The mean inter-item correlation coefficients of the personality dimensions vary from 0,36 to 0,49 , which compare favourably with the range of 0,15 to 0,50 recommended by Clark and Watson (1995).

Table 3 shows the product moment correlation coefficients between the NEO-PI-R and job performance.

TABLE 3

Product-Moment CORRELATION COEFFiCIENTS BETWEeN THE NEO-PI-R AND THE PAO

\begin{tabular}{lccc}
\hline Item & Task Performance & Creativity & Management \\
\hline Neuroticism & $-0,11$ & $-0,22$ & $-0,31$ * \\
Extraversion & 0,17 & 0,22 & 0,21 \\
Openness & 0,13 & 0,26 & 0,41 * \\
Agreeableness & 0,07 & 0,10 & 0,31 * \\
Conscientiousness & 0,05 & 0,11 & 0,10 \\
\hline
\end{tabular}

* Practically significant correlation (medium effect): $d \geq 0,30$

Table 3 shows practically significant correlation coefficients (of medium effect) between Management Performance on the one hand and Neuroticism (negative correlation), Openness to Experience and Agreeableness (both positive correlations). No practically significant correlation coefficients were found between personality dimensions on the one hand and Task Performance and Creativity on the other hand.

A canonical correlation was performed between a set of personality dimensions and two aspects of job performance,
Task Performance and Creativity, using SAS CANCORR. Shown in the tables are correlations between the variables and canonical variates, standardised canonical variate coefficients, within-set variance accounted for by the canonical variate (percent of variance), redundancies and the canonical correlations. The results of the canonical analysis are shown in Table 4. The set of personality traits included Neuroticism, Extraversion, Openness to Experience, Agreeableness and Conscientiousness. The performance set included Task Performance and Creativity.

TABLE 4

Results OF THE CANONICAL ANALYSIS: PERSONALITY DIMENSIONS AND PERFORMANCE

\begin{tabular}{lcc}
\hline & \multicolumn{2}{c}{ First Canonical Variate } \\
\hline & Correlation & Coefficient \\
\hline Personality dimensions set & & \\
Neuroticism & $-0,65$ & $-0,73$ \\
Extraversion & 0,51 & $-0,06$ \\
Openness to Experience & 0,75 & 0,78 \\
Agreeableness & 0,23 & $-0,05$ \\
Conscientiousness & 0,35 & $-0,04$ \\
Percent of variance & 0,28 & \\
Redundancy & 0,04 & \\
Performance set & & $-0,76$ \\
Task performance & & 1,49 \\
Creativity & 0,42 & \\
Percent of variance & 0,89 & \\
Redundancy & 0,48 & \\
Canonical correlation & 0,07 & \\
\hline
\end{tabular}

The first canonical correlation was 0,38 (15\% overlapping variance), and the second was 0,13 ( $2 \%$ overlapping variance). With both canonical correlations included, $F(10$, $298)=2,76, p<0,01$. Subsequent F-tests were not statistically significant. The first pair of canonical variates, therefore, accounted for the significant relationships between the two sets of variables. Data on the first pair of canonical variates appear in Table 4. Total percentage of variance and total redundancy indicate that this pair of canonical variates was moderately related.

With a cut-off correlation of 0,30 the variables in the personality dimensions set that were correlated with the first canonical variate were Neuroticism, Extraversion, Openness to Experience and Conscientiousness. Among the performance variables, Task Performance and Creativity correlated with the first canonical variate. This pair of canonical variates indicate that emotional stability (low Neuroticism) $(-0,65)$, Extraversion $(0,51)$, Openness to Experience $(0,75)$ and Conscientiousness $(0,35)$ are associated with Task Performance $(0,42)$ and Creativity $(0,89)$.

The results of a stepwise regression analysis with the Big Five personality dimensions as independent variables and Management (as measured by the PAQ) are shown in Table 5. 
TABLE 5

MULTIPLE REgReSSION ANALYSIS REgARDING PERSONALITY DIMENSIONS AND MANAGEMENT

\begin{tabular}{lcccc}
\hline \multicolumn{5}{c}{ ANALYSIS OF VARIANCE } \\
\hline $\boldsymbol{R}=\mathbf{0 , 4 8}$ & $\begin{array}{c}\text { Source of } \\
\text { variance }\end{array}$ & $\begin{array}{c}\text { Degrees of } \\
\text { freedom }\end{array}$ & $\begin{array}{c}\text { Sum of } \\
\text { squares }\end{array}$ & Mean square \\
\hline$R^{2}=0,28$ & Regression & 8 & 4068,75 & 813,75 \\
$F=5,60 \quad f^{2}=0,38$ & Residual & 73 & 10613,12 & 145,39 \\
\hline \multicolumn{5}{c}{ VARIABLES IN THE EQUATION } \\
\hline Independent variables & Parameter & Standard & $\boldsymbol{F}$ & $\boldsymbol{p}$ \\
\multicolumn{5}{c}{ error } \\
Intercept & 32,98 & 21,67 & 1,52 & 0,1324 \\
Neuroticism & $-0,16$ & 0,08 & $-1,89$ & 0,0622 \\
Extraversion & $-0,05$ & 0,08 & $-0,67$ & 0,5069 \\
Openness & 0,29 & 0,08 & 3,48 & 0,0008 \\
Agreeableness & 0,16 & 0,07 & 2,15 & 0,0352 \\
Conscientiousness & $-0,05$ & 0,09 & $-0,60$ & 0,5529 \\
\hline
\end{tabular}

Table 5 shows that personality dimensions predict $28 \%$ of the variance in Management (as measured by the PAQ). The multiple correlation of 0,48 is practically significant (large effect) $\left(\mathrm{f}^{2}=0,38\right)$. Table 6 shows that Openness to Experience and Agreeableness are the best predictors of performance in Management.

\section{DISCUSSION}

Analysis of the product-moment correlations between personality dimensions, task performance and creativity showed that no practically significant relationships existed. However, the results of the canonical analysis showed that a combination of emotional stability (i.e. low Neuroticism), Extraversion, Openness to Experience and Conscientiousness explained about $15 \%$ of the variance in task performance and creativity.

It seems that employees who tend towards Neuroticism (i.e. who are prone to having irrational ideas, being less able to control impulses, and coping poorly with stress) perform poorer and are less creative than those who are emotionally stable. This result confirms the findings of Hörmann and Maschke (1996), Dunn et al. (1995) and Judge et al. (1999). Furthermore, Extraversion was associated with task performance and creativity, probably because of the fact that extraverts tend to experience positive affect (Clark \& Watson, 1991).

The results of the canonical analysis confirmed that Openness to Experience is related to task performance and creativity. Employees who are open to experiences show an active imagination, aesthetic sensitivity, attentiveness to inner feelings and a preference for variety, all of which explain why they are rated higher on their performance and creativity at work. This result confirms the findings of researchers such as Horton (1992) and Raudsepp (1990). Conscientiousness was also associated with task performance and creativity, although the loading of Conscientiousness was relatively lower in the personality set. However, it makes sense that conscientious employees perform better compared to less conscientious employees (Barrick \& Mount, 1991; Barrick et al., 1993; Borman et al., 1991; Hough et al, 1990).

Furthermore, personality dimensions were related to management performance. Emotional Stability, Openness to Experience and Agreeableness were practically significantly related to management performance. Managers who are emotionally stable, open to experience and agreeable tend to perform better than those who measured lower on these dimensions. The negative relationship between Neuroticism and managerial performance may be explained by the fact that managers who score high on Neuroticism are prone to having irrational ideas, are less able to control their impulses, and cope poorly with stress. The significant relationship between Openness to Experience and managerial performance could be explained by the fact that managers in the pharmaceutical company continuously have to adapt to changes (see Horton, 1992; Raudsepp, 1990) because the company is relatively young and has grown fast since it was established. The results show that personality dimensions predict $28 \%$ of the variance in managerial performance.

A possible explanation for the lack of relationships between personality dimensions and task performance is that the tasks of employees in the pharmaceutical organisation are well-defined, with relatively low autonomy allowed. According to Barrick (2001), personality dimensions are most likely to affect job performance in situations where autonomy is high.

This study had various limitations. Firstly, a predictive validity design was not used, which could have affected the magnitude of the correlation coefficients obtained. A disadvantage of this design is that poor performers have probably already resigned from the company. Secondly, the sample consisted largely of females, which implies that the results could not be generalised to males. Thirdly, the results cannot be generalised to other settings. Lastly, the research design does not allow one to determine the direction of the relationships obtained.

\section{RECOMMENDATIONS}

The results of this study confirm that the pharmaceutical company should consider the personality dimensions of their employees when predicting creativity and managerial performance during selection and career development. However, more research is needed before these results are used to predict job performance because they were not obtained in a selection context. Furthermore, because relatively poor associations between personality dimensions and job performance were obtained, future research efforts should be directed at the effects of personality on performance through motivation.

The relationship between personality dimensions and job performance should be studied with larger samples and by using predictive validity designs in various South African organisations. The effects of cultural differences and language on the relationship between personality dimensions and job performance should also be studied.

\section{REFERENCES}

Ashton, M.C. (1998). Personality and job performance: The importance of narrow traits. Journal of Organizational Behavior, 19, 289-303.

Barrick, M.R. \& Mount, M.K. (1991). The big five personality dimensions and job performance: A meta-analysis. Personnel Psychology, 44, 1-26.

Barrick, M.R. \& Mount, M.K. (1993). Autonomy as a moderator of the relationship between the Big Five personality dimensions and job performance. Journal of Applied Psychology, 78, 111-118.

Barrick, M.R., Mount, M.K. \& Strauss, J.P. (1993). Conscientiousness and performance of sales representatives: Test for the mediating effect of goal setting. Journal of Applied Psychology, 78, 715-722. 
Barrick, M.R. \& Mount, M.K. (1996). Effects of impression management and self-deception on the predictive validity of personality constructs. Journal of Applied Psychology, 81, 261-272.

Barrick, M. R., Mount, M. K., \& Judge, T. A. (2001). Personality and performance at the beginning of the new millennium: What do we know and where do we go next? International Journal of Selection and Assessment, 9, 9-30.

Bing, M.N. \& Lounsbury, J.W. (2000). Openness and job performance in U.S.-based Japanese manufacturing companies. Journal of Business and Psychology, 14, 515-522.

Borman, W.C., White, L.A., Pulkos, E.D. \& Oppler, S.H. (1991). Models of supervisor job performance ratings. Journal of Applied Psychology, 76, 863-872.

Boshoff, C. \& Arnolds, C. (1995). Some antecedents of employee commitment and their influence on job performance. South African Journal of Business Management, 26 (4), 125-135.

Clark, L.A. \& Watson, D. (1991). General affective dispositions in physical and psychological health. In C.R. Snyder \& D.R. Forsyth (Eds.) Handbook of social and clinical psychology: The health perspective. New York: Pergamon.

Clark, L.A. \& Watson, D. (1995). Construct validity: Basic Issues in objective scale development. Psychological Assessment, 7, 309-319.

Cohen, J. (1988). Statistical power analysis for the behavioural sciences (2nd ed.). Hillsdale, NJ: Lawrence Erlbaum \& Associates

Costa, P.T. \& McCrae, R.R. (1988). Personality in adulthood: A six-year longitudinal study of self-reports and spouse ratings on the NEO Personality Inventory. Journal of Personality and Social Psychology, 54, 853-863.

Costa, P.T. \& McCrae, R.R. (1992). Revised NEO Personality Inventory (NEO-PI-R) and NEO Five Factor Model (NEO-FFI) professional manual. Odessa, FL: Psychological Assessment Resources.

Day, D.V. \& Bedeian, A,G, (1995). Personality similarity and work-related outcomes among African-American nursing personnel: A test of the supplementary model of personenvironment congruence. Journal of Vocational Behaviour, $46,55-70$.

De Fruyt, F. \& Mervielde, I. (1999). RIASEC types and Big Five traits as predictors of employment status and nature of employment. Personnel Psychology,52, 701-727.

Digman, J.M. (1989). Five robust trait dimensions: Development, stability, and utility. Journal of Personality, 57, 195-214.

Dunn, W.S., Mount, M.K., Barrick, M.R. \& Ones, D.S. (1995). Relative importance of personality and general mental ability in managers' judgements of applicant qualifications. Journal of Applied Psychology, 80, 500-509.

Frink, D.D. \& Ferris, G.R. (1999). The moderating effects of accountability on the conscientiousness-performance relationship. Journal of Business and Psychology, 13, 515-524.

Goldberg, L.R. (1990). An alternative "description of personality": The big five factor structure. Journal of Personality and Social Psychology, 59, 1216-1229.

Goldberg, L.R. (1993). The structure of phenotypic personality traits: Authors' reactions to the six comments. American Psychologist, 48,1303-1304.

Guion, R.M. \& Gottier, R.F. (1965). Validity of personality measures in personnel selection. Personnel Psychology, 18, 135-164.

Hackman, J. \& Oldham, G. (1980). Work redesign. Reading, MA: Addison-Wesley.

Hamilton, E.E. (1988). The facilitation of organisational change. An empirical study of factors predicting change agents' effectiveness. Journal of Applied Behavioural Science, 24, 37-59.

Hayes, T.L., Roehm, H.A. \& Castellano, J.P. (1994). Personality correlates of success in total quality manufacturing. Journal of Business and Psychology, 8, 397-411.
Hogan, R., Hogan, J. \& Roberts, B.W. (1996). Personality measurement and employment decisions: Questions and Answers. American Psychologist, 51, 469-477.

Hough, L.M., Eaton, N.K., Dunnette, M.D., Kamp, J.D. \& McCloy, R.A. (1990). Criterion-related validities of personality constructs and the effect of response distortion on those validities. Journal of Applied Psychology, 75, 581-595.

House, R.J., Shane, S.A., \& Herold, D.M. (1996). Rumours of the death of dispositional research are vastly exaggerated. Academy of Management Review, 21, 203-224.

Hörmann, H. \& Maschke, P. (1996). On the relation between personality and job performance of airline pilots. The International Journal of Aviation Psychology, 6, 171-178.

Jang, K.L., Livesley, W.J. \& Vernon, P.A. (1996). Hereditability of the big five personality dimensions and their facets: A twin study. Journal of Personality, 64, 577-591.

Johnson, J.A. (1997). Seven social performance scales for the California Psychological Inventory. Human Performance, $10,1-30$.

Judge. T.A., Higgins, C.A., Thoresen, C.J. \& Barrick, M.R. (1999). The big five personality traits, general mental ability, and career success across the life span. Personnel Psychology, 52, 621-652.

Krilowicz, T.J. \& Lowery, C.M. (1996). Evaluation of personality measures for the selection of textile employees. Journal of Business and Psychology, 11, 55-61.

Lowery, C.M. \& Krilowicz, T.J. (1994). Relationship between nontask behaviours, rated performance and objective performance measures. Psychological Reports, 74, 571-578.

McCrae, R.R. \& Costa, P.T. (1987). Validation of the fivefactor model of personality across instruments and observers. Journal of Personality and Social Psychology, 52, 81-90.

McCrae, R.R. \& Costa, P.T. (1997). Personality trait structure as human universal. American Psychologist, 52, 509-516.

Nunnally, J. \& Bernstein, I.H. (1994). Psychometric theory (3rd ed.). New York: McGraw-Hill.

Ones, D.S. \& Viswesvaran, C. (1997, July). Empirical and theoretical considerations in using conscientiousness measures in personnel selection. Paper presented at the 5th European Congress of Psychology, Dublin, Ireland.

Ones, D.S., Viswesvaran, C. \& Reiss, A.D. (1996). Role of social desirability in personality testing for personnel selection: The red herring. Journal of Applied Psychology, 81, 660-679.

Raudsepp, E. (1990). Are you flexible enough to succeed? Manage, 42, 6-10.

Reilly, R.R. \& Warech, M.A. (1993). The validity and fairness of alternatives to cognitive tests. In C.C. Wing \& B.R. Gifford (Eds.), Policy issues in employment testing (pp. 131-224). Norwell, MA: Kluwer Academic.

Rosse, J.G., Stecher, M.D., Miller, J.L. \& Levin, R.A. (1998). The impact of response distortion on pre-employment personality testing and hiring decisions. Journal of Applied Psychology, 83, 634-644.

Sackett, P.R. \& Wannek, J.E. (1996). New developments in the use of measures of honesty, integrity, conscientiousness, dependability, trustworthiness and reliability of personnel selection. Personnel Psychology, 49, 787-830.

Salgado, J.F. (1997). The five-factor model of personality and job performance in the European Community. Journal of Applied Psychology, 82, 30-43.

SAS Institute. (1996). SAS Users Guide: Basics (6 $6^{\text {th }}$ ed.) Cary, NC: SAS Institute.

Schepers, J.M. (1994). Die konstruksie en evaluering van 'n prestasiebeoordelingsvraelys vir nie-akademiese personeel. Johannesburg: RAU.

Schmitt, N., Gooding, R., Noe, R. \& Kirsch M. (1984). Metaanalysis of validity studies published between 1964 and 1982 and the investigation of study characteristics. Personality Psychology, 37, 407-422. 
Schneider, M.H. (1999). The relationship of personality and job settings to job satisfaction. Dissertation Abstracts International: Section B: Science and Engineering, 59, 6103.

Shaughnessy, J.J. \& Zechmeister, E.B. (1997). Research methods in psychology (4th ed.). New York: McGraw-Hill

Stewart, G.L. \& Carson, K.P. (1995). Personality dimensions and domains of service performance. A field investigation. Journal of Business and Psychology, 9, 365-378.

Steyn, H.S. (1999). Praktiese betekenisvolheid. Die gebruik van effekgroottes. Wetenskaplike bydraes - reeks B: Natuurwetenskappe Nr. 117. Potchefstroom: PU vir CHO.

Strümpfer, D.J.W., Danana, N., Gouws, J.F. \& Viviers, M.R. (1998). Personality dispositions and job satisfaction. South African Journal of Psychology, 28, 92-100.
Tabachnick, B.G. \& Fidell, L.S. (2001). Using multivariate statistics (4th ed.). Boston, MA: Allyn \& Bacon.

Tett, R.P., Jackson, D.N. \& Rothstein, M. (1991). Personality measures as predictors of job performance: A meta-analytic review. Personnel Psychology, 44, 703-742.

Tokar, D.M. \& Subich, L.M. (1997). Relative contributions of congruence and personality dimensions to job satisfaction. Journal of Vocational Behaviour, 50, 482-491.

Vinchur, A.J., Schippmann, J.S., Switzer, F.S. \& Roth, P.L. (1998). A meta-analytic review of predictors of job performance for salespeople. Journal of Applied Psychology, 83, 586-597.

Wright, P.M., Kacmar, K.M., McMahan, G.C. \& Deleeuw, K. (1995). Cognitive ability and job performance. Journal of Management, 21, 1129-1139. 